\title{
Reform of Mixed Classroom Teaching Mode Based on Online Open Course
}

\author{
Ligong Sun*, Lipeng Zhou, Xinwen Niu \\ Electrical Engineering College \\ Henan University of Science and Technology \\ Luoyang, China \\ 471023
}

\begin{abstract}
The combination of traditional classroom learning and online Open course learning is becoming an important direction of current university teaching reform. This paper introduces the advantages of mixed class and the existing problems. The mixed classroom construction situation in our school explained the hardware and software environment needed for the implementation of the mixed classroom. It focused on the design and implementation of the electrotechnic mixed classroom te aching model based on the online open curriculum, and explore the direction of mixed classroom development in the future.
\end{abstract}

Keywords - online open courses; mixed classroom; teaching video; teaching mode

\section{INTRODUCTION}

In recent years, with the development and application of network information technology, online open course has become an important direction of teaching reform at home and abroad. In addition, the mixed classrooms combining traditional classroom teaching and online open courses has drawn more and more attention and developed rapidly. Mixed classroom has the advantages of both online learning and traditional classroom learning, which not only embodies the main role of learners, promotes students' creativity and initiative, but also plays the leading role of teachers, thus improving the efficiency of learning as a whole.

In order to improve the teaching quality of undergraduates, domestic colleges and universities have put in manpower and material resources to carry out the construction of online open courses and the hardware construction of mixed classroom teaching environment in order to promote the reform of mixed classroom teaching mode based on online open course.

\section{THE ADVANTAGES OF MIXED CLASSROOMS OVER TRADITIONAL CLASSROOMS}

Traditional teaching focuses on the classroom, emphasizing the transfer of knowledge and information while neglecting the process of absorbing and digesting knowledge. As a result, the classroom is occupied by teachers to do knowledge transfer, rather than for teacher-student interaction, peer collaboration and communication. The process of absorbing and digesting knowledge was placed in the afterschool session, which often makes students get into trouble because of the lack of help. Therefore, effects of

Henan University of Science and Technology 2017 Teaching Research and Teaching Reform Key Funding Project, No. 2017YBZD007. learning are unsatisfactory. The innovation of the mixed classroom is to break this long-standing practice in the teaching field. In this way, students learn the basic concept and knowledge through teachers' explanation in the online video out of class. When they go back to classroom, they can have face-to-face discussions with teachers and complete exercises, with the focus of absorbing and digesting knowledge. This innovation of teaching has many prominent advantages

- It provides free learning space for students. Modern students are open-minded. They participate in social activities more than before. Thus, their time is more limited. Online learning gives students flexible time and breaks the space limit. Student can lean not only in the classroom, but also in any other places.

- Students become the main role in the class. The mixed class has changed the roles of teachers and students. The teacher only plays a guiding role in the teaching process. Students can think independently, ask questions, put forward ideas, discuss, and debate with each other. Their enthusiasm is ignited and there is more interaction between them than before.

- It can cultivate students' teamwork spirit. Class discussions are usually organized in groups. Students can help each other to learn, communicate and mutually support.

- It can improve the students' learning effect. In mixed class, students can discuss, exchange ideas, ask and answer questions under the guidance of teachers. The problems can be solved in time. Students will no longer frustrated or loss motivation of study due to lack of assistance as before. Teachers can also communicate with students one-on-one and provide personalized tutoring. Teaching students in accordance of their aptitude can improve students' learning effect obviously.

\section{THE LIMITATIONS IN MIXED CLASSROOM MODE}

- It has to ensure the quality of pre-class learning. The biggest problem in mixed classrooms is that all students must be fully prepared before entering the classroom. All of them have read the video completely 
and have a basic understanding of the teaching content. Otherwise, the atmosphere is not suit for discussing. When the teacher talks about the content, it is difficult to go deep. Sometimes they even have to repeat. The teaching effect of mixed classroom requires the teaching videos to be appealing enough and the students to be enabled to do self-study and self-control.

- It requires qualified hardware and software resources. The online-offline teaching mode requires professional teaching team with expertise and information technology quality. The teaching team should set teaching goals, refine the knowledge points, record the teaching videos, and make teaching courseware and other types of multimedia teaching resources for the courses. The online teaching platform is the channel for students to learn. Students can acquire teaching resources through online teaching platform and communicate with each other. The multi-functional interactive classrooms provide students with places to study and discuss together and carry out panel discussions, cooperation, sharing and inquiry-based teaching.

- Teachers should change their concepts. Some teachers recognized video merely as a substitute for explanation or a means of reducing their workload. They devoted little effort to the overall process-design of the mixed classrooms and only repeated the videos' content. As a result, students feel dry and boring because of repetition, and the classroom discussions were not heated but dreary. Under this circumstance, the teaching effect is certain to be unsatisfactory.

- The large number of students in each class is a big problem. Many domestic colleges and universities use large-class mode, which frequently contains seventy to eighty or even over one hundred students in each class. Such a large number of students make it impossible for teachers to tutor students one-to-one. There are two ways to solve this problem: the first is to make more teaching videos which contain the common problems as many as possible. Students can choose and watch these videos by themselves. The second is to encourage students to help each other. They can set up groups to do cooperative learning and discuss with each other. In this way, teachers' pressure and load can be relieved effectively.

\section{The Construction of Mixed Classroom Teaching MODE}

The construction of mixed classroom teaching mode requires essential hardware and software resources. Based on this, our school improves online teaching platform and builds a university-level platform for online open courses, and uses the online open curriculum teaching platform of Henan province (icourses.cn) to promote the construction of province-level and university-level quality online open courses. On the other hand, it has invested in the construction of virtual recording studios and multifunctional classrooms to prepare hardware conditions for the development of mixed classrooms.
At present, there are 9 online open courses at province-level and over 10 online open courses at university-level in our university. Most of them have applied the newly-built multifunctional classrooms to carry out the reform of the mixed classroom teaching mode.

After meeting the basic requirements of hardware and software resources, our university has put forward an outline of construction of mixed classrooms combined with online and offline learning characteristics and with reference to the experience of brother colleges and universities, as shown in Fig. 1.

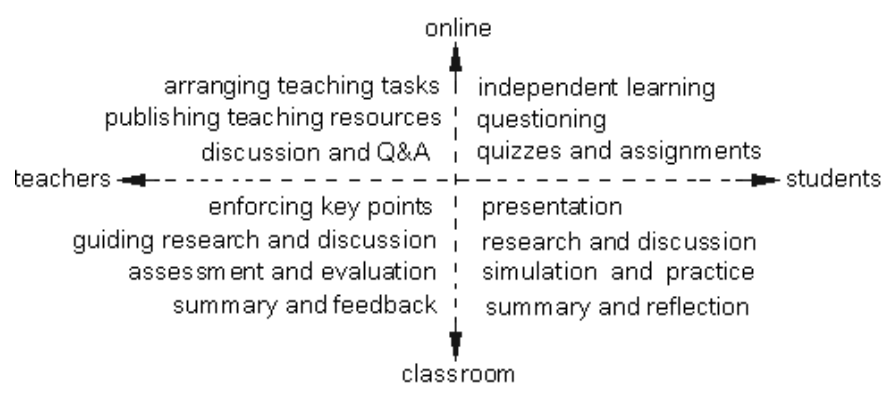

Fig. 1. Mixed Classroom Teaching Mode

\section{Design of MiXed Classroom Teaching in ELECTROTECHNICS}

The course of "Electrotechnics" is the earliest course run by our university in Henan Province online open curriculum teaching platform (icourses.cn), and we adopted the mixed classroom teaching mode in the course teaching of our "excellent class". The reason for choosing "excellence class" as the experimental subject is that the "excellent class" uses small class teaching mode. The number of students is usually 30 to 60 in order to facilitate group discussion and research in the course teaching.

The mixed classroom teaching of Electrotechnics based on the online open curriculum is divided into three parts: preclass part, classroom part and after-class part. The specific activities of each part are as follows:

- Pre-class part: This part is mainly based on students' independent study. Students are expected to study by watching teaching videos, learn to summarize knowledge points, complete the online discussion questions and assignments according to the syllabus. This part aims to cultivate students' ability to use knowledge to analyze problems at a preliminary level.

- Classroom part: According to the students' feedback before class, the teachers should estimate the students' learning situation, determine the key points in teaching and design the mixed classroom teaching plan with teaching contents, methods and goals.

In this part, students become the main role in the class. The teachers' task is to preside and guide the class process with a variety of methods, such as discussion, inquiry and questioning. This will give students more opportunities to express themselves. For the incomplete 
and inaccurate aspects in students' presentation, teachers will make complement and summary. Besides, teachers should also coordinate the class process and evaluate the performance of students.

In the class, students learn together in groups. The group discussions, questioning and competitions can help to create a good learning atmosphere and cultivate students' awareness of cooperation.

- After-class part: According to the contents of the class, students are expected to construct and consolidate knowledge structures to deepen understanding, and to complete after-class assignments to have all-round ability training.

\section{IMPLEMENTATION EFFECT}

In the past one year, mixed classroom teaching mode of electrotechnics the open and online course has shown the remarkable effect through the comparison between experimental class and regular class. The academic performance of experimental class is obviously better than that of regular class.

- The teaching effect of experimental class has improved significantly. As the students have watched the teaching videos according to the requirements before class, they have had a basic understanding of the key points. On the other hand, teachers are not only teaching, but also organizing discussions. Students are required to make summary of the content of courses. Therefore, most of them are concentrated and take an active part in class, which will gradually develop their independent thinking and judgment.

- Despite that the test paper of experimental class had a higher degree of difficulty; the results of 2017 final examination have shown that the scores of the experimental class are obviously higher than those of the regular class.

As can be seen from Table 1, the average scores of the experimental class are higher than those of the regular class by more than 4 points. The excellent rate of the experimental class is about $20 \%$ higher than that of the regular class, while the failure rate of the experimental class is $14 \%$ lower than that of regular class. These have proved that the new teaching mode had obviously improved the learning effect of experimental class.

TABLE I.

COMPARISON OF FINAL EXAMINATION SCORES BETWEEN THE EXPERIMENTAL CLASS AND THE REGULAR CLASS

\begin{tabular}{|c|c|c|c|c|c|c|}
\hline & \multicolumn{3}{|c|}{$\begin{array}{c}\text { Electrotechnics 1 } \\
\text { (2016-2017-2) }\end{array}$} & \multicolumn{3}{c|}{$\begin{array}{c}\text { Electrotechnics 2 } \\
(2017-2018-1)\end{array}$} \\
\hline Class & $\begin{array}{c}\text { Average } \\
\text { score }\end{array}$ & $\begin{array}{c}\text { Excellent } \\
\text { rate }\end{array}$ & Failure rate & $\begin{array}{c}\text { Average } \\
\text { score }\end{array}$ & $\begin{array}{c}\text { Excellent } \\
\text { rate }\end{array}$ & Failure rate \\
\hline $\begin{array}{c}\text { Experimental } \\
\text { Class }\end{array}$ & 76.5 & 53.3 & 10.0 & 75.8 & 46.8 & 8.3 \\
\hline Regular Class & 72.2 & 32.7 & 24.5 & 71.7 & 27.6 & 22.4 \\
\hline
\end{tabular}

- A later survey about students' satisfaction has shown that $85 \%$ of the students are satisfied with the mixed classroom teaching mode. $73 \%$ of the students consider that the new teaching mode has improved their concentration on class and helped to improve their academic performance. Another survey towards students of regular class has shown that $72 \%$ of the students are willing to apply the mixed classroom teaching mode.

\section{CONCLUSION}

The teaching practice of "Electrotechnics" course in our university has illustrated that the reform of the mixed classroom teaching mode based on the online open curriculum has gained remarkable effect. It changed the previous teaching mode mainly based on the teachers' lectures. Students could choose time and places to learn freely. Since they have changed from the "audience" who passively accept the knowledge under the dais to the participants and subjects in the class, their enthusiasm and initiatives have been improved greatly. Students had more freedom under the guidance of teaching tasks. Therefore, the teaching effect and students' academic performance have gained obvious improvement.

\section{REFERENCES}

[1] Cao Yang, Wan Zong, Chen Jingran. "Universities Mixed Class Status and The Improved Strategy, ” [J]. China University Teaching, 2014, no.12, pp.81-84.(In Chinese).

[2] Zhao Xiaohong. "The Application of Blended Learning Mode in University Teaching.” [J].Business, 2015, no.1, pp.283-283.(In Chinese)

[3] Ren Ling, Cen Honglei, Zhang Ning. "Research of Flipped Class Teaching Design on Electronic Technology Course.”[J]. Journal of Electrical \& Electronic Education, 2017, Vol.39, no.2, pp.66-69.(In Chinese).

[4] Zhang Qiliang, Wang Aichun. "The Design of New Blended Learning Model Based on Flipped Classroom,"[J]. Modern Educational Technology, 2014, no.4, pp27-pp32.(In Chinese).

[5] Chen Yanxiu. "Flip Classroom Teaching Reform Practice of Circuit Principle Based on the MOOC.” [J]. Journal of Electrical \& Electronic Education, 2016, Vol.38, no.2, pp.43-45.(In Chinese).

[6] Xu He. “Online open courses construction plan research,” [J]. Journal of Higher Education, 2016, no.5, pp.109-110.(In Chinese).

[7] Ren Youqun, Xu Shimeng. "The Exploration of and Reflection upon Open Courseware: From Learners, Decision-Makers to Constructors.” [J]. Modern Distance Education Research, 2013, no.5, pp.3-10.(In Chinese) 